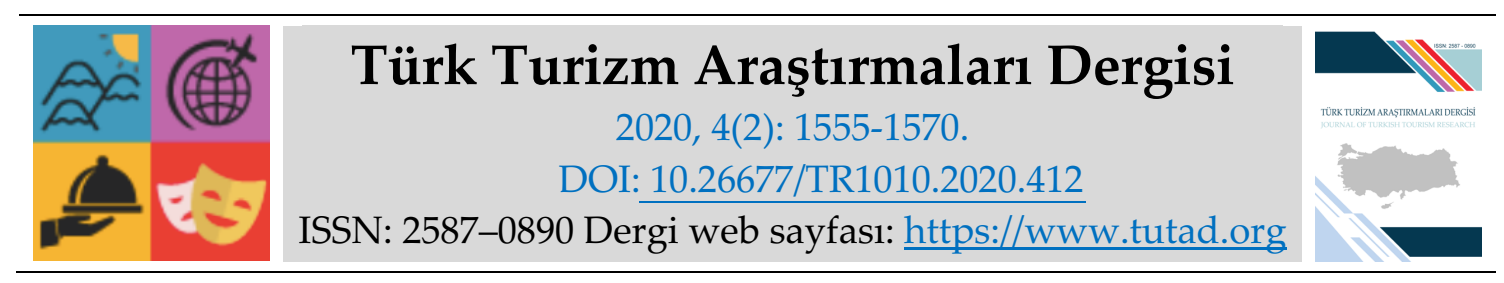

ARASTIRMA MAKALESI

\title{
Kalkınma Ajanslarının Kentlerin Turizm Ürünü Olarak Markalaşmasındaki Önemi: İstanbul Kalkınma Ajansı Örneği*
}

Dr. Öğr. Üyesi Ertuğrul DÜZGÜN, Gümüşhane Üniversitesi, Turizm Fakültesi, Gümüşhane, eposta: duzgunertugrul@gmail.com

ORCID: https://orcid.org/0000-0002-0786-3840

Öz

Kentlerin ve turistik destinasyonların kalkınabilmeleri için projeler üretilmesi gerekmektedir. Kalkınma Ajansları da projelerin üstlenicilerinden birisidir. Çalışmada İstanbul Kalkınma Ajansı'nın (İSTKA) bulunduğu kentin; turizm potansiyelinin artırılmasına, sürdürülebilirliğine, markalaşma sürecine katkısı ve destinasyonların kalkınma ajansları için önemi irdelenmiştir. Ayrıca ajansların hedefleri ile ulaştıkları sonuçlar arasındaki uyum ortaya çıkarılmaya çalışılmıştır. Araştırmanın amaçlarını gerçekleştirmek için İstanbul Kalkınma Ajansı örnek olay çalışması olarak seçilmiştir. Çalışmada nitel araştırma yöntemlerinden olan yarı yapılandırılmış görüşme tekniği kullanılmıştır. Cevaplar yarı yapılandırılmış anket formu ile toplanmıştır. Betimsel analize tabi tutulan araştırmada, İSTKA'nın kentlerin turizm potansiyelinin artırılmasında, sürdürülebilir ve marka bir bölge olmasında önemli katkılarının olduğu görülmüştür. Özellikle bölgedeki diğer kuruluşlarla iş birliği yaparak, şehrin markalaşmasına önemli yenilikler getirdiği ve konuyla ilgili birçok projeyi desteklediği belirlenmiştir.

* Bu çalışma 14. Geleneksel Turizm Panelinde sunulmuş olan bildirinin genişletilmiş halidir.

Anahtar Kelimeler: Kent Markalaşması, Destinasyon Markalaşması, İstanbul Kalkınma Ajansı.

Makale Gönderme Tarihi: 25.10.2019

Makale Kabul Tarihi: 01.04 .2020

\section{Önerilen Atıf:}

Düzgün, E. (2020). Kalkınma Ajanslarının Kentlerin Turizm Ürünü Olarak Markalaşmasındaki Önemi: İstanbul Kalkınma Ajansı Örneği, Türk Turizm Araştırmaları Dergisi, 4(2): 1555-1570.

(c) 2020 Türk Turizm Araştırmaları Dergisi. 


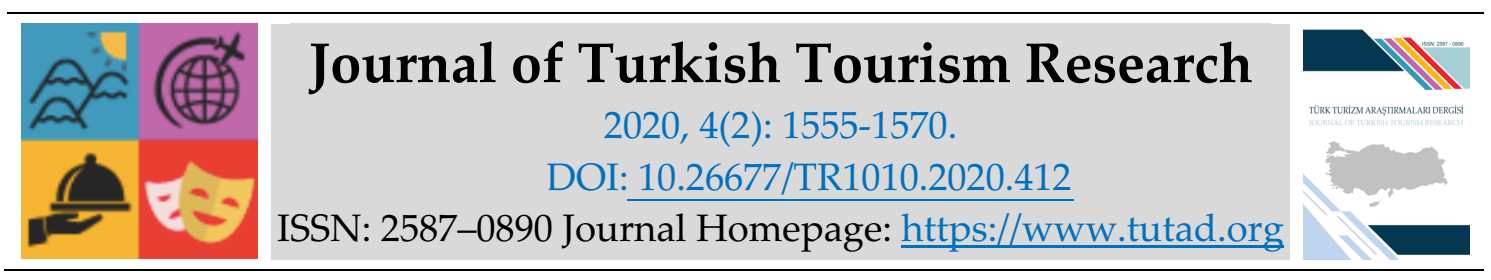

\title{
RESEARCH PAPER
}

\section{The Importance of Development Agencies in City Branding as a Tourism Product: Case of İstanbul Development Agency}

Assistant Prof. Dr. Ertuğrul DÜZGÜN, Gümüşhane University, Faculty of Tourism, Gümüşhane, e-mail: duzgunertugrul@gmail.com ORCID: https://orcid.org/0000-0002-0786-3840

\begin{abstract}
Projects are needed to be produced in order to developing the cities and tourist destinations. One of the suppliers of these projects is development agencies. In this study, the city where the İstanbul development Agency is located, is examined for the enhancing the tourism potential, the sustainability of the contribution to the branding process and the importance for the development agencies of destinations. Also attempt to bring harmony between the results they achieve with the goals of the agency. İstanbul Development Agency has been selected as a case study to realize the objectives of the research. In this study, the Semi-structure interview technique, which is qualitative research method, is used. For this purpose, semi-structured survey form applied. In the descriptive analysis research, İstanbul Development Agency, contributes to increasing the tourism potential of the city, sustainable and branding the city. It is determined that, especially cooperating with the other companies, in the area, brings important innovations to branding the city and supporting lots of project, relating the subject.
\end{abstract}

Keywords: City Branding, Destination Branding, İstanbul Development Agency.

Received: 25.10 .2019

Accepted: 01.04.2020

\section{Suggested Citation:}

Düzgün, E. (2020). The Importance of Development Agencies in City Branding as a Tourism Product: Case of İstanbul Development Agency, Journal of Turkish Tourism Research, 4(2): 15551570.

(C) 2020 Türk Turizm Araştırmaları Dergisi. 


\section{Gíriş}

Kentler için önem teşkil eden konuların başında şehrin markasını oluşturması gelmektedir. Bu süreç birbiri ardına belirli faaliyetlerin gerçekleştirilmesi ile meydana gelmektedir. Türkiye'de yeni yeni başlanan kent markalarının oluşturulma sürecinde, kente ait turistik değerlerin çıkarılması, vizyon belirleme, kamu-özel sektör ve sivil toplum kuruluşları ile tüm yerel halkın bu sürece dahil edilmesi gerekmektedir. Bu konudaki diğer önemli etmen ise yerel yöneticilerin şehrin markasının oluşmasına gereken önemi en üst düzeyde vermesi ve gereken katkıyı sağlaması noktasında olmaktadır (Giritlioğlu ve Avcıkurt, 2010). Ergun'a (2012) göre bölgesel ekonomik kalkınmada kentler büyük öneme sahiptir. Çünkü kent yönetimleri çeşitli projeler kanalıyla sermayeleri kendi kendilerine çekmekte ve küresel bazda rekabet üstünlüğü sağlamaktadır. Bu üstünlükleri sağlamak için bölgesel bazda örgütlenmiş olan Kalkınma Ajansları proje üretme ve geliştirme görevlerini yerine getirmektedir.

Gelişen ve artan rekabet ortamında kentler farklı oldukları yönleri ortaya koyup, kendilerine olumlu bir kimlik kazandıracakları markalaşma çalışmaları yapmaktadır. Bu noktada birbirinden farklı niteliklere sahip olan kentlerin bazıları daha avantajlı konumda olabilmektedir. Ancak burada dikkat edilmesi gereken nokta mevcut olan değerlerin niteliği veya niceliği değil, bunların doğru kullanımı veya sunumudur. Bu doğrultuda da marka yaratma stratejileri özellikle turizm pazarlamacılarının ilgisini çeken önemli bir konu olmaktadır. Doğru bir şekilde oluşturulmuş olan marka stratejileri turistik tüketicilerin kente yönelik olan algılarını turizm pazarlamacılarının hedefleri doğrultusunda şekillendirebilir (Kanıbir, Nart ve Saydan, 2010: 56).

Araştırmanın İstanbul ilinin varlık ve faaliyetlerinin belirlenmesi, bahsedilen varlık ve faaliyetlerin şehrin markalaşmasına etkisini ölçmesi ve Kalkınma Ajanslarının kentlerin markalaşma sürecine katkılarının görülebilmesi açısından önemli olduğu düşünülmektedir. Araştırmanın amacıysa, İstanbul Kalkınma Ajansının TR10 bölgesinin turizm potansiyelinin artırılması, sürdürülebilir ve marka bir bölge olmasında ne gibi katkılar sağladığının ortaya konulması olarak belirlenmiştir.

\section{LITERATÜR TARAMASI}

\section{Kent Markalaşması ve Turizmde Marka Kent Olma}

Marka, sadece ürünün ismi, logosu ve ambleminden ibaret değildir (Diker, 2018: 45). Marka kavramı; marka kişiliği, marka imajı, marka değeri, marka farkındalığı, markanın konumlandırması gibi önemli unsurları içerisinde barındırmaktadır (Can ve Başaran, 2014: 39). Bu yüzden sadece işletmeler ve ürünleri ile sınırlandırılacak kadar kısıtlı bir kavram değildir. Çünkü ürün ve şirketler ile birlikte ülkeler, kentler ve insanlar da birer marka olabilmektedir. Çünkü marka, karşı tarafa vermiş olduğu anlam ve çağrışımlar sayesinde tıpkı bir etiket görevi üstlenmektedir. Buna ilaveten güçlü ve büyük markalar; ürünlerine, hizmetlerine ve yerlerine renk ve ses gibi ilave etkinlikler katmaktadır (Kotler, 2004: 12).

Kentlerde sunumu yapılan ve bütünleşik deneyimler olarak adlandırılan tüm mal ve hizmetler, tüketim faaliyetini sağlayanlarca o yerin markası ile ilişkili olarak algılanmakta ve o kentin markası olarak tüketilmektedir (Buhalis, 2000). Bir kentin güçlü bir marka olabilmesi için öncelikle o kentte markayı destekleyecek değerler ve özellikler bulunmalıdır. Kentte iyi bir markaya sahip olmak için önemli bir değerin var olmadığı durumda, oranın ayırt edici başka bir niteliği sahiplenmesi gerekmektedir. Bakıldığında kent markası; insanların deneyimlerini, görüşlerini, inançlarını ve davranışlarını da içerisine almaktadır (Özdemir ve Karaca, 2009). 
Kentlerin marka kent olabilmek için sergiledikleri çabalara bakıldığında; kente gelen ziyaretçi sayısını çoğaltması, kente yapılan yatırımları artırması, kente eğitim ve yaşamak için daha fazla kişinin gelmesinin sağlaması sayılabilir. Bu çabalar ile kente ait güçlü yönlerin belirlenmesi, kentte farklılık yaratılması, şehre değer ve sağlam bir imaj kazandırması hedeflemektedir (Can ve Başaran, 2014: 39). En önemli güçlü yönlerden biri ise tarihi geçmiştir. Tarihi geçmişe sahip olan kentler, bu özelliğinin farkına vardığında, özelliğini kentin tanıtım faaliyetlerinde ve kent markası oluşturma sürecinde yoğun bir şekilde kullanmaktadır. Bu bakımdan tarihsel ve kültürel değerlerin yoğun şekilde bulunduğu kentler, diğer kentlere göre daha avantajlı konumdadır. Marka kent olma ile ilgili kentlerin sahip olduğu diğer bir önemli avantaj ise coğrafi konumdur. Bu sayede çok sayıda kent, markalaşma yolunda önemli adımlar atmıştır. Özellikle deniz imkânı olan kentler tanıtım faaliyetlerine bu niteliklerini de ekleyerek kısa sürede önemli yollar kat etmişlerdir (Özkul ve Demirer, 2012).

Diğer yandan Kent markası oluşum süreci de markalaşma faaliyetlerinde büyük önem taşımaktadır. Türkiye'de ilk kez kentsel bazda marka kent olma projesi ise 2023 Türkiye Turizm Stratejisi ile gündeme gelmeye başlamıştır. Bu strateji; gelişim koridorları ve gelişim ana aksları, turizm kentleri, turizm gelişim bölgeleri, eko-turizm bölgeleri ve marka kent üzerinde yoğunlaşmaktadır (Kültür ve Turizm Bakanlığı, 2007; Tek, 2009).

Eroğlu (2007) kent markasının oluşum sürecini beş aşamadan oluşan bir model ile anlatmıştır. Sürecin ilk aşamasını kente özgü olarak gelişen marka stratejik analizi oluşturmaktadır. Bu aşama, ikinci aşamadaki marka kimliğinin oluşturulmasını sağlamaktadır. Diğer aşamada ise farkındalığ 1 sağlamak ve marka değerini oluşturmak gelir. Son aşama ise markanın konumlandırılmasıdır. Bu sayede markanın tüketicilerin zihnine yer etmesini sağlamak amaçlanmaktadır. Hanna ve Rowley (2008), kentler için markayı zorunluluk haline getiren unsurları; uluslararası seyahatlerin maliyetlerinin azalması, medyanın yükselen gücü, sundukları değerler açısından kentler arası benzerliklerin artması, tüketim gücünün ve insanların farklı kültürlere olan ilgilerinin artması olarak sıralamışlardır. Tekin ve Cici (2011) ise kentlerin markalaşması için gerekli olan 6 unsurun var olduğunu savunmuşlardır. Bunlar; özel sektör ve diğer kuruluşlar, yerel yönetim politikası ve dış ilişkiler, yatırım ve yerleşim, turizm, kongre ve aktiviteler, eğitim ve spor, kültür tarihi, miras ve işaretler gibi temel unsurlardan oluşmaktadır. İlgüner ve Asplund'a (2011) göre kentler, kendilerine özgü olan değerleri kullanarak marka haline gelebilirler. Günümüzde ülkelerin yerine kentler, hatta kasabalar marka yaratmanın gerekliliğini savunmaktadır. Markalaşmada üzerinde durulması gereken temel konu vaat edilenin verilmesi hususudur. Çünkü kentte gerçek bir imajın oluşturulması için bu konuya vurgu yapılması gerekmektedir (Zeren, 2012; 98). Porter'a (1995) göre kentler gerçek anlamda rekabet etmektedirler. Fakat bu rekabet tahmin edildiği gibi, para birimlerindeki faiz oranları ya da kur farklılıkları veya dünya ticaretinden pay alma ile yapılmamaktadır. Onların rekabet biçimleri; nüfusu, turizmi, yatırımları ve teşvikleri kendi kentlerine çekerek şekillenmektedir.

Turizmde ülkelerden ziyade destinasyonların markalaşması ve marka kent olma çalışmaları artmaya başlamıştır. Son dönemlerde yapılan turizm etkinlikleri farklı özellikleri vurgulayıcı etmenler üzerinde yapılmaya başlamış ve bunlara yönelik olarak yapılan pazarlama faaliyetleri de hız kazanmıştır. Turizm talebinde ortaya çıkmış olan bu değişimler sayesinde kentlerin ve destinasyonların pazarlanması önem kazanmıştır. Günümüzde ülkelerin sahip oldukları tek bir destinasyonu pazarlamak yerine, bölge ve kentlerin pazarlanması anlayışı önem kazanmıştır. Bölgesel bazda pazarlamadan kentsel bazda pazarlamaya geçilmesi ise turizm açısından ülkesel riskleri azaltıı bir etken olmayı sağlamıştır (Tosun ve Bilim, 2004).

Bir kentten bahsedildiğinde kente ait bir özne, yapı veya sosyolojik bir durum akla geliyorsa o kentin sağlamış olduğu marka olgusundan bahsetmek mümkün olabilmektedir. Örneğin; 
Hasankeyf, Kapadokya, Pamukkale gibi turistik alanlar bağlı bulundukları ilçe veya kent merkezlerinin dışında komple bir bölgeyi markalaştırabilmektedir. Ancak buralarda ortaya çıkan bir sorun da bulunmaktadır. Çünkü yerli ve yabancı çoğu turist, Kapadokya'nın bağlı olduğu il olan Nevşehir'e hiç uğramadan Kapadokya'yı ziyaret etmekte ve bölgeden ayrılmaktadır (Toksarı, İsen ve Dağcl, 2014: 329).

Kent markalarını oluşturan semboller genellikle anıt ve yapılardan oluşmakta ve bunlar da marka kişiliğini oluşturmaktadır. Örneğin; Roma için tarihi geçmişi olan Kolozyum, Mısır için dünyanın yedi harikası olarak anılan Piramitler, Rusya için devasa Kremlin Sarayı, Paris için aşıklar simgesi olan Eyfel Kulesi gibi. Marka kişiliği yaratmada önemli bir unsur ise kültürel sembollerden faydalanmaktır. Örneğin, tarihsel geçmişi çok eskilere dayanmayan Teksas'ın en etkili kültürel sembolü kovboylarıdır. Ülkemizde ise Konya denildiğinde akla gelen ilk kültürel sembol Mevlâna olmaktadır (Can ve Başaran, 2014: 30). Dubai ve Batum gibi gerek tarihsel yönden gerekse kültürel yönden önemli bir potansiyelin olmadığ bölgelerde ise, iyi bir stratejik yönetimle marka kent oluşturulabilmektedir (İçellioğlu, 2014: 45).

\section{Kalkınma Ajansları}

Ajanslar, bir bölgenin sahip olduğu içsel dinamikleri harekete geçirmek ve Küçük ve Orta Büyüklükteki İşletmeleri (KOBİ) bilgi, teknoloji ve kaynak yönünden desteklemek amaciyla kurulmuş olan aracı kurumlardır. Kamunun karar gücünü kamu organlarından alarak özel sektör ve sivil toplum kuruluşları gibi paydaşlardan oluşan tüzel kişiliklere dağıtan yönetici kuruluş olma görevini üstlenmişlerdir (Özer, 2012: 37).

Kalkınma ajansları ise bölgeler arasında rekabet ortamı oluşturmak, aralarındaki gelişmişlik farklarını azaltmak ve bölgelerdeki tüm ilgililerin girişimcilik ruhlarını desteklemek amacıyla uygulama ve koordinasyon görevini üstlenen kuruluşlar olarak tanımlanabilir. Buradaki amaç, bölgelerin üstün oldukları yanlar belirlenerek o alana yönelik gerek ulusal gerekse uluslararası alanda yatırımların teşvik edilmesini sağlamaktır. Bu yapının sağlanabilmesi için de bölgede çok sayıda projenin üretilmesi gerekmektedir (Işık vd., 2010: 14).

Son yıllarda ülkemizde yapılan kalkınma faaliyetlerinde bölgesel gelişme politikalarının her geçen gün öneminin arttı̆̆ı söylenebilir. Bu dönemde köklü bir değişim sürecine uğramış olan bölgesel gelişim politikalarına, Avrupa Birliği üyelik süreci ve küresel gelişmelerde meydana gelen değişimlerin etkilerinin olduğu kadar yerel dinamiklerin de etkisi olmaktadır. Buna bağlı olarak da DPT Müsteşarlığı küresel, bölgesel ve yerel ihtiyaçlara cevap verebilmek adına yerelde Kalkınma Ajansları örgütlenmelerini hayata geçirmişlerdir. Bölgesel olarak örgütlenmiş olan Kalkınma Ajanslarının, bölgesel kalkınmadaki köklü değişimin temel kurumsal yapı taşlarından olduğu söylenebilmektedir (Akpınar, 2010: 10).

5449 sayılı kanunun 5. maddesinde ajansların görev ve yetkileri aşağıdaki gibi sıralanmıştır (Şimşek, 2013: 18);

- Bağlı olduğu bölgenin rekabet gücünü desteklemek,

- Bölgenin gelişim stratejilerini hazırlamak,

- Kamu, özel işletmeler ve sivil toplum kuruluşları arasında iş birliği sağlamak,

- Bölgedeki iş ve yatırım imkanlarını araştırmak ve tanıtımını yapmak,

- Bölgedeki örgütlerin sahip oldukları kapasitelerinin artmasına katkı sunmak,

- Kirsal kalkınmayı desteklemek,

- Girişimcilere yapmış oldukları faaliyetlerde destek vermek,

- Yerel yönetimlerdeki planlama çalışmalarına teknik yönden destek vermek, 
- Yatırımcıların ruhsat ve izin işlemlerinin tek elden takibini ve koordinasyonunu sağlamak olarak sıralanabilir.

Bu görevleri yerine getirebilmek üzere Türkiye'de faaliyetlerine devam eden toplamda 26 tane Kalkınma Ajansı bulunmaktadır. Ajansların teşkilât yapısı; Yönetim Kurulu, Kalkınma Kurulu, Genel Sekreterlik ve buraya bağlı Planlama, Programlama- Koordinasyon Birimi, Program Yönetim Birimi, İzleme-Değerlendirme Birimi, Yatırım Destek Ofisi ile Destek Ofisinden meydana gelmektedir. Kalkınma Ajansları 2018 yılı itibariyle de Sanayi ve Teknoloji Bakanlığı Kalkınma Ajansları Genel Müdürlüğüne bağlı olarak hizmetlerini sürdürmektedirler (www.istka.org.tr).

Kalkınma ajansları ile ilgili mevcut literatüre bakıldığındaysa Çiftçi, Çakır ve Çakır (2016) Trakya Kalkınma Ajansının Trakya Bölgesi turizmi üzerindeki etkisini belirlemeye yönelik olarak yapmış oldukları çalışmada Trakya Kalkınma Ajansı'nın hibe desteklerinin yanı sıra kendisinin de yürüttüğü turizm tabanlı projeler olduğu belirtilmiştir. Ayrıca planlar ve projeler hazırlanırken bölgedeki paydaşların da sürecin içerisine dâhil edilmesi gerektiği önerilmiştir. Çelik (2017) bölgesel kalkınma ajanslarının sosyal kalkınmaya katkısını İzmir Kalkınma Ajansı özelinde değerlendirmiş ve toplum yararlı yapılan projeler ile çocuk yazarların yetiştirildiği, engelli bakım merkezlerinin kurulduğunu ve organik oyuncaklar kurulduğunu, ayrıca bu projeler kapsamında eğitim ve istihdam noktasında da kaynak sağlandığını belirtmiş̧tir. Akpınar ve Keskin'in (2018) Zafer kalkınma ajansının Manisa ekonomisine katkısını belirlemeye yönelik olarak yapmış olduğu çalışmada, kalkınma ajanslarının yerel kalkınma için önemi ifade edilerek bölgeye sunmuş olduğu mali destek programlarının olumlu sonuçları açıklanmıştır. Uçar ve Başaran (2019) kalkınma ajanslarının girişimcilik ve istihdam üzerindeki etkilerini belirlemeye yönelik olarak yaptıkları araştırmada özellikle sanayi ve imalat sektörü üzerinde önemli katkılarının olduğundan bahsetmişlerdir. Araştırma sonucuna göre Kalkınma ajansının bölgeye girmesiyle birlikte sanayi ve imalat sektörü hızlanmıştır.

\section{YÖNTEM}

Çalışmanın amacı İstanbul ilinin rekabet avantajı elde etmesinde ve marka şehir olmasında Kalkınma Ajansının sağladığı katkıları belirlemektir. Bu amaçla İstanbul Kalkınma Ajansı'nın bulunduğu bölgeye ve il marka imajının oluşturulmasına olan katkıları belirlenmeye çalışılmıştır. Araştırmayla markanın TR10 bölgesinde bulunan İstanbul ilinin turizm potansiyelinin artırılmasına, markalaşma sürecine ve sürdürülebilirliğine katkısı belirlenmeye çalışılmıştır. Bölgedeki varlıklar ile faaliyetlerin belirlenmesi ve TR10 bölgesinin markalaşmasında hangi bileşenlerin daha etkili olacağının tespit edilmesi illerin markalaşması yolunda önemli faydalar sağlayacaktır. Bu tespiti yapabilmek ve derinlemesine bilgi sağlayabilmek için ilgili alan yazın incelenmiş ve literatürdeki çalışmalardan (Özkul ve Demirer, 2012; Cevher, 2012; Polat ve Özdemir-Yılmaz, 2014) toplam 14 maddeden oluşan açlk uçlu bir soru formu hazırlanmıştır.

Türkiye genelinde toplamda 26 adet kalkınma ajansı bulunmaktadır. Bu ajanslardan çalışmanın başlığında da belirtildiği üzere İstanbul bölgesini kapsayan TR10 Bölgesi araştırmaya dahil edilmiştir. Araştırmada amaçlı örnekleme yöntemlerinden ölçüt örnekleme yöntemi kullanılmıştır. Amaçlı örnekleme geniş bilgilere sahip olduğuna inanılan durumlarda derinlemesine araştırmaya imkân vermektedir. Bu örnekleme türünde öncelikle seçim için önemli görülen ölçütler belirlenmekte ve bu ölçütlere göre seçilen örneklemin de araştırmanın evrenini tüm nitelikleri ile temsil ettiği varsayılmaktadır (Tavşancıl ve Aslan, 2001: 90; Yılmaz ve Özdem, 2004: 121; Büyüköztürk, 2014). Nitel araştırma yöntem ve teknikleri daha fazla zaman ve emek harcaması sebebiyle küçük örneklemler üzerinde yapılmaktadır. Bazen örneklem amaçlı 
bir şekilde seçilmiş olan (n=1) uzman kişiyle de yapılabilir (Patton, 1990:169). Böyle durumlarda istatistiki temsil edilebilirlik yerine örneklemin daha derinlemesine, bütünsel ve konu bağlamında anlaşılmayı sağlayacak bilgilerin alınacağı kişilerin tespit edilmesi önemlidir (Türnüklü, 2000: 548). Lincoln ve Guba (2010) da nitel çalışmalarda örneklemin büyüklüğü veya küçüklüğü yerine örneklemin araştırmacının gereksinim duyduğu bilgi miktarını karşılayıp karşılayamadığıyla ilgilenilmesini önermiştir. Benzer şekilde Patton (19990: 169) da amaçlı olarak seçilen örneklemin seçimindeki ana hedefin, çalışılacak konu ile ilgili olarak daha fazla bilgi sunacak olan kişilerin seçilmesinin temel amaç olduğunu ve sayı konusunda esnek olunması gerektiğini ifade etmiştir. Buradan hareketle araştırmaya başlamadan önce İSTKA yönetimiyle görüşmeler yapılarak araştırma hakkında ön bilgi verilmiş ve konunun uzmanlarının kim olduğu hakkında bilgiler istenmiş, sonrasında kurumun vermiş olduğu uzman/kilit kişilerden görüşme için randevu alınmıştır.

Örnek olay olarak seçilen İSTKA'ya yönelik olarak yapılan araştırmadaki görüşmelerde toplam 14 sorudan oluşan yarı yapılandırılmış bir soru cetveli kullanılmıştır. Sorular sırasıyla ve yönlendirmeden uzak bir şekilde yüz yüze olarak sorulmuştur. 2015 yılı Mart ayında yapılan görüşmeler zaman, emek ve maliyet açısından İstanbul Kalkınma Ajansındaki yetkililerle sınırlandırılmıştır. Görüşme süreleri yaklaşık 60 dakika sürmüş ve ses kayıt cihazı kullanılarak kayıt altına alınmıştır. Elde edilen görüşler betimsel analize tabi tutulmuştur. Betimsel analizler, derinlemesine analiz gerektirmeyen veriler işlenirken kullanılmakta, aynı zamanda görüşme yapılan bireyleri tanıtıcı bulgular da değerlendirilmektedir (Yıldırım ve Şimşek, 2008: 89). Soru formuna ve ses kaydına alınan veriler çalışmada önce doğrudan alıntılar şeklinde verilmiş ardından ise yorumlanmıştır.

\section{BULGULAR}

Araştırmanın bu bölümünde "Kentlerin Turizm Ürünü Olarak Markalaşmasında Kalkınma Ajanslarının Önemini" belirlemeye yönelik olarak yapılan görüşmeler sonucunda elde edilen cevaplardan benzer soruları çözümleyebilmek için analiz kısmında tema ve alt kategoriler oluşturulmuştur. Bunlar Tablo 1’de verilmiştir.

Tablo 1. Araştırmada Kullanılan Temalar ve Alt Kategoriler

Üst Tema: Kentlerin Turizm Ürünü Olarak Markalaşmasında Kalkınma Ajanslarının Önemi

Alt Kategori 1: Kentin avantajları ve İSTKA tarafından bu avantajların nasıl algılandığı

Alt Kategori 2: Şehrin dezavantajları

Alt Kategori 3: Şehrin sahip olduğu soyut imaj unsurları

Alt Kategori 4: Kalkınma ajansının turizm potansiyelinin artırılması ve sürdürülebilirliği yönünde ne gibi katkılar sağladığı

Alt Kategori 5: Yapılan markalaşma çalışmaları

\section{Alt Kategori 1: Kentin Avantajları ve İSTKA Tarafından Bu Avantajların Nasıl Algılandığı}

Bir kentin gelişebilmesinde, tanttılabilmesinde ve turizmden beklenen getiriyi elde edebilmesinde kentin gerek jeopolitik yönden gerek tarihi ve doğal yönden gerekse de sosyo- 
kültürel yönden birtakım avantajlarının olması şehre artı değer katabilecektir. Bu kapsamda araştırma alanı olan İstanbul için "İnsanları İstanbul'a çeken şey nedir? Insanlar İstanbul'a neden gelir?" sorusu yöneltilmiştir. Katılımcı, ziyaretçilerin İstanbul'a daha çok belirli bölgeleri görmek ve kültür turizmi amaçlı geldiklerini belirtmiş ve gelen kişilerin de kalış sürelerinin kısa olduğunu ifade etmiştir. Görüşü destekler şekilde Türkiye'ye gelen turistlerin konaklama işletmelerinde ortalama kalış süreleri Kültür ve Turizm Bakanlığının 2019 yılı sonu verilerine göre 2.61 olarak gerçekleşmiştir (www.ktb.gov.tr). Konuyla ilgili olarak katılımcının görüşü aşağıdaki gibidir:

“İstanbul'a insanlar özellikle belli bölgeleri görmeye gelmektedirler. Bu yüzden kalış süreleri de genel olarak kısa olmaktadır. Yeni alternatif turizm çeşitleri başlasa da insanlar İstanbul'a daha çok kültür turizmi için gelmektedirler. Ayrıca İstanbul önemli bir iş merkezi durumuna gelmiştir. Bu yüzden iş seyahati için ciddi bir şekilde insan akışı olmaktadır. Diğer bir nokta ise İstanbul'un birçok alanda tüm Türkiye'ye hizmet verebilmesidir. Özellikle sağllk sektöründeki hizmetten faydalanmak için İstanbul'a gelinmektedir. Bu da yakın çevre için önemli bir çekim unsuru olabilmektedir. Diğer bir etmen belirli bir kesimin eğlence ve kültürel aktiviteler için İstanbul'a gelmesidir".

Metropol bir şehir olan İstanbul'un tercih edilmesinde birtakım olanakların olduğu söylenebilir. Özellikle büyük bir nüfusu bünyesinde barındırması sebebiyle nitelikli insan kaynağını, farklı coğrafyalardan gelip yerleşen insanlar olduğu için zengin bir kültürel değeri barındırdığ söylenebilir. Ayrıca genç nüfusunda yoğun olarak bölgede bulunması sebebiyle güçlü bir işgücü ve istihdam kaynağının da varlığından bahsedilebilir. Konuyla ilgili olarak "İstanbul'un tercih edilen bir il olabilmesi için sahip olduğu olanaklar nelerdir ve bu olanaklar yapılan çalışmalarda ne derecede kullanılmaktadır?" sorusu yöneltilmiş ve katılımcı şu şekilde cevaplandırmıştır:

“Türkiye'ye kıyasla İstanbul'da; nitelikli insan kaynağı, zengin kültürel değer, büyük bir dinamizm ve genç nüfus kaynağı bulunmaktadır. Turistler açısından bakıldığında ise kültürel değerler önem taşımaktadır. Ayrıca Batılı toplumların aklında Doğu ile özdeşleşen birtakım değerler de bulunmaktadır".

\section{Alt Kategori 2: Şehrin Dezavantajları}

Türkiye'ye gelen 2019 yllı sonu itibariyle 45.058.286 turistten 14.906.663'ü İstanbul'u tercih etmiştir (www.istanbul.ktb.gov.tr). Başka bir deyişle Türkiye'ye gelen her 3 turistten 1'i İstanbul'a gelmiştir. Ülke turizminde büyük bir paya sahip olan İstanbul'un dezavantajl veya zayıf olabileceği alanlar katılımcılara sorulmuştur. Konuyla ilgili olarak "İstanbul'un en zayıf olduğu alanlar sizce nelerdir?" sorusuna katılımcıdan gelen cevap aşağıdaki gibidir:

"Istanbul'a gelen kişilerin bilgilendirme konusunda sorun yaşadıkları düşünülmektedir. Bu konuda hazırlanmış olan mevcut bir İstanbul haritası dahi bulunmamaktadır. Bu konuyla ilgili ISTKA tarafindan bir çalıştay yapılmıştır. Bu konudaki paydaşlar bir araya getirilmiş ve İstanbul haritasının içeriğginde neler olması gerektiği konusu tartışılmıştır. Mevcut bulunan İstanbul haritalarını oteller yaptırmakta ve bunlar da niteliksiz olmaktadır. Çünkü bu haritalarda yeni tanıtmayı düşünülen kültürel değerler bulunmamaktadır. Diğer önemli bir zayıf nokta ise standartlar konusundadır. Hem personelin standartları hem de sunulan ürünün standartları konusunda sıknntılar bulunmaktadır. Çünkü belli bir standartta ürün ya da hizmet sunulamamaktadır".

Türkiye İstatistik Kurumu (2019) verilerine bakıldığında Türkiye'nin turizmden elde ettiği gelir 2019 yılı sonu itibariyle 34 milyar 520 milyon 332 bin dolardır. Toplam gelire bakıldığında turizm bacasız sanayi konumundadır. Ancak turizmi olumsuz yönde etkileyen güvenlik, hizmet kalitesi ve ulaşım gibi konularda olumsuzluklar yaşanabilmektedir. Bu noktada "İstanbul'da turizmi olumsuz yönde etkileyen sorunlar sizce nelerdir?" sorusuna katılımcının vermiş olduğu cevap şu şekildedir: 
"Küresel kentlerle kıyaslandığında güvenliğe dayalı algı olumsuz yönde olmaktadır. Diğer bir konu ise turistlerle doğrudan iletişim halinde olan sektörlerde çalışan kişilerin davranıs modelleriyle ilgili olabilmektedir. Bu konularda ciddi değişikliğe gidilmesi gerekmektedir. Turistlerin hareket ettikleri alan belli olduğu için ulaşım konusunun olumsuz olacağı tarafımdan düşünülmemektedir".

\section{Alt Kategori 3: Şehrin Sahip Olduğu Soyut İmaj Unsurları}

Bir şehrin gerek dış dünyadaki bilinirliği gerekse akılda kalış şekli o şehrin tercih edilmesinde büyük önem taşımaktadır. Örneğin dünyada bilinen şehirlere bakıldığında sakin, ucuz, temiz, güvenli, gelişmiş, yenilikçi ve dışa açı gibi unsurlar gelmektedir. Bu bakımdan İstanbul gibi önemli bir şehrin soyut imajını belirleyebilmek üzere sorulan "Sizce İstanbul'un sahip olduğu soyut imaj unsurları nelerdir?" sorusuna alınan cevap aşağıdaki şekildedir.

"İstanbul, dışa açık ama bir yandan da muhafazakâr bir şehirdir. Çelişkilerin, gelir adaletsizliğinin, her şeyin uç noktalarının bulunduğu, muazzam bir enerjinin olduğu ve bu kadar pahahısını Avrupa'da dahi zor bulacağınız yerleri bulunmaktadır. Bu bakımdan İstanbul çelişkilerin şehri olarak tarif edilebilir. İstanbul'un temizliği konusunda ise sıkıntı bulunmaktadır. Örnek olarak Viyana'da insanların yağmur yağdığında ayakkabılarını çıkararak çıplak ayakla yürümeleri, temizliği gösteren önemli bir unsur olarak karşımıza çıkmaktadır".

Şehirlerin bugünden uzun vadedeki geleceklerini planlamaları gerekmektedir. Özellikle kendi ülkeleri özelinde ve dünya genelinde hangi boyutları ile ön plana çıkacaklarının belirlenebilmesi önemlidir. Bu bakımdan bugünden yarını planlamak ve ona yönelik çalışmalar yürütmek, o şehirdeki paydaşları ilgilendiren en hassas konulardan biridir. Konuyla ilgili olarak katılımcıya sorulan “Günümüzde İstanbul, Türkiye'de ve dünyada hangi boyutlar ile öne çımaktadır? Gelecek 20 yılda, hangi boyutları ile öne çıkabilir?" sorusuna alınan yanıt şu şekildedir:

“Günümüzde İstanbul Türkiye'de ve dünyada ekonomik güç olarak öne çıkmaya başlamıştır. Bu durum Türkiye'nin değişen rolüyle birlikte tetiklenmiştir. Farklı sektörlerde bir yatırım alanı olarak ön plana çıkmaya başlamıştır. Gelecek 20 yılda İstanbul'un potansiyeli düşünüldüğünde; Ar-Ge, İnovasyon ve Yaratıcllı sektörleri ve bu sektörlerde çalışan kişileri çeken bir şehir olarak öne çıkabilecektir".

\section{Alt Kategori 4: Kalkınma Ajansının Turizm Potansiyelinin Artırılması ve Sürdürülebilirliği Yönünde Ne Gibi Katkılar Sağladığı}

Bir şehirdeki turizm potansiyelinin artması sadece o sektörde hizmet veren turizm işletmelerine katkı sağlamakla kalmayıp ülke tanıtımı ve ülke milli gelirindeki artış gibi daha büyük boyuttaki konulara da faydalar sunabilecektir. Kalkınma Ajanslarının "Oluşturulan stratejik planda İstanbul ili turizmi için öncelikli olarak ele alınan konular nelerdir?" sorusuna yönelik verilen cevap şu şekildedir:

İstanbul turizm için öncelikli olarak rekabetçiliğin artırılması, İstanbul'un bir destinasyon olarak değerinin artırlması, turizmin altında ise İstanbul'da turizmin çeşitlendirilmesi, geçirilen gün sayısının artırılması, turizm gelirlerinin artırılması gibi konular bulunmaktadır. Diğgr yandan turistik destinasyonlarm kapasitesi bellidir. Oralara aşırı yüklenmeler ise kültürel değerlerimize de zarar vermektedir. Örneğin Ayasofya müzesinin ziyaretçi kapasitesi çok yoğun kullanılmaktadır. Bu durum belli bir sinırda tutulmalı ve değeri artırılmalıdır. Talep eden kişilerin randevulu olarak ve yüksek ücret ödeyerek gelmeleri gerekmektedir".

Turizmden gelir elde etmek için birçok turistik değerlerini pazarlayan bölgelerin/ülkelerin yanı sıra çok fazla alternatif turizm faaliyeti yapılmaya imkânı olup, bu değerlerini kullanamayan destinasyonlar da vardır. Öncelikle şehirlerin sahip oldukları turistik değerlerinin farkında olması ve buna göre alternatif turizm faaliyetlerini planlamaları büyük önem taşımaktadır. 
Türkiye özelinden bahsedilecek olursa deniz-kum-güneş üçlüsü onlarca yıldır turizmde tanıtım ve konumlandırma çalışmalarında yapılmaktadır. Ancak bakıldığında ülkemizde Kültür ve Turizm Bakanlığının (2020) belirlemiş olduğu sağlık ve termal, yayla, mağara, av, kongre, golf, yat, ipek yolu, inanç, hava sporları, dağcılık, akarsu-rafting, su altı dalış ve kuş gözlemciliği turizmi olmak üzere çok sayıda alternatif turizm çeşidi bulunmaktadır. Katılımcıya "illde hangi alternatif turizm faaliyetlerinin geliştirilmesi hedefleniyor? Belirlenen turizm türleri için şimdiye kadar yapmış olduğunuz çalışmalar nelerdir?" sorusu yöneltilmiş ve aşağıdaki cevap alınmıştır:

Yakın zamanda sağlık turizmi çalıştayında görüşülmüş̧ür. Onun dışında başka mali destekler de olmuştur. İş ve fuar turizmi, yat(kurvaziyer) turizmi bunlar içerisinde sayllabilir. Bunun dışında İstanbul'un potansiyelinin çok olmadığı alanlar da bulunmaktadır. Bunların çözümü için yakın çevreyle iş birliği içerisine girerek çözüme kavuşturmak gerekmektedir. Örneğin İstanbul'a yakın bir il olan Bursa'ya termal için gelen bir kişi belli bir dönemi de İstanbul'da geçirebilir. Bu şekilde bölgelerarası iş birliği să̆lanabilirse Türkiye'deki geceleme sayısı artabilecektir. Diğer yandan sağllk turizmine bakıldığında kültür turizmi, iş turizmi ve golf turizmiyle birlikte değerlendirildiği görülmektedir.

Şehirler sahip oldukları değerlerin farkına vardıklarında daha güçlü planlar yaparak gelecekle ilgili stratejilerini şekillendirebileceklerdir. İstanbul da tarihsel süreç içerisinde çok sayıda medeniyete ev sahipliği yapmış olması, merkezi konumu ve doğal güzellikleriyle ön planda olan bir şehirdir. İstanbul'un görünen yüzü kadar turizm potansiyeli olup da perde arkasında çok sayıda turistik değeri de bulunmaktadır. Katılımcıya "İstanbul ilinin kullanılmayan turizm potansiyellerinin (değerler ve yöreler) ön plana çıkması için yapmış olduğunuz çalışmalar nelerdir?" sorusu yöneltilerek bu potansiyeller hakkındaki ve bununla ilgili olarak yaptıkları hakkında bilgiler alınmıştır:

"Ajansin amaci strateji geliştirmek, desteklemek ve bu stratejileri hayata geçirmektir. Mali destek programıyla belirli hedefler koyarak kişilere proje çă̆rısı yapılmaktadır. Paydaşlarımıza İstanbul'un bütününe yansıyan proje teklifönerileri sunuyoruz. Bu gelen projelerin içinde turizm potansiyeline yönelik olarak Kuzey Ormanlarına ve Beykoz Ormanlarma yönelik projeler geliştirilmiştir. Kurum olarak sektörler de farklılaşmayı desteklemektedir. Örneğin alternatif turizm türlerine yönelerek İstanbul'un tüm bölgesine yayma ve hizmet kalitesini artırma gerekliliğini savunuyoruz".

Sürdürülebilirlik birçok alanda olduğu gibi turizmde de sosyal, ekonomik ve çevresel etkileri olan bir kavramdır. Kalkınma ajansı gibi toplum ve kamu faydasına yönelik faaliyetler üreten kuruluşların da devamlılığın sağlanması için yapmış olduğu faaliyetler kaçınılmaz olmaktadır. Buradan hareketle "Turizmde sürdürülebilirliğin sağlanması için hangi konulara öncelik verilmesi gerektiğini düşünüyorsunuz?" sorusu yöneltilmiş ve şu cevap alınmıştır:

"Koruma kullanma dengesine dikkat edilmesi gerekmektedir. Ayasofya örneğinde olduğu gibi yapıyı koruyarak kullanmak esas alınmalıdır. Ayrıca ekonomik sürdürülebilirliği de mutlaka göz önünde bulundurmak gerekmektedir. Sadece korumak ayn zamanda o yapının ekonomik bir değer üretmesini sağlamak gerekmektedir. Bu noktada kültürel değerler bizim üstümüzde yok olmaktan çıabilmelidir".

\section{Alt Kategori 5: Yapılan Markalaşma Çalışmaları}

"Kamu kesimi, özel kesim ve sivil toplum kuruluşları arasındaki iş birliğini geliştirmek, kaynakların yerinde ve etkin kullanımını sağlamak ve yerel potansiyeli harekete geçirmek suretiyle, ulusal kalkınma planı ve programlarda öngörülen ilke ve politikalarla uyumlu olarak bölgesel gelişmeyi hızlandırmak, sürdürülebilirliğini sağlamak, bölgeler arası ve bölge içi gelişmişlik farklarını azaltmak" amacıyla kurulan Kalkınma Ajanslarının bu faaliyetlerinin yanı sıra bulundukları bölgenin markalaşma çalışmalarına da katkı sağladığı düşünülmektedir. Bu vesileyle sorulan "Şehrinizi bir marka haline getirmek adına gerçekleştirdiğiniz faaliyetler var mıdır? Varsa neler olduğunu açıklayabilir misiniz?" sorusuna verilen cevap aşağıdaki şekildedir: 
"Istanbul'u marka haline getirmek için ajans tarafından doğrudan çalışmalar yapılmamaktadır. Bu işlem farklı kurumlarla iş birliği yaparak yürütülmektedir. İstanbul Tanıtım Ofisi'nin kurulmasıyla ilgili farklı kurumlarla iş birliği yapılarak süreç devam ettirilmektedir. İstanbul'u marka şehir haline getirebilmek için mali destek programları çok önemli bir etkendir. Bu anlamda çok fazla kuruma çok sayıda destek verilmiştir. Gerek İstanbul'daki sağlık turizmini uluslararası alanda marka haline getirmek, gerek İstanbul'un bir fuar merkezi olması yönünde yapılan çalışmalara çok sayıda mali destekler verilmiştir. Örneğin, turizmi çeşitlendirmek ve güçlendirmek için 2 dönem boyunca mali destekler verilmiştir".

Bir şehrin markalaşmasını sağlamak ve markalaşma sürecini yönetmek tek bir kurumun görevi olmaktan ziyade tüm paydaşların katılımıyla oluşacak ortak akıl ile meydana gelebilecektir. Kuruluş amacı kamu, özel sektör ve sivil toplum kuruluşlarını bir araya getirmek olan Kalkınma Ajansı yetkilisine "Kurumunuz şehrin markalaşma sürecinin neresinde yer almaktadır?" sorusu iletişmiş ve aşağıdaki cevap alınmıştır:

“Kurumumuz eğer şehrin markalaşması konusunu odağına alırsa komple bu konu üzerinde çalışabilir. ISTKA İstanbul'un farklı alanlarda bir dünya kenti olmasına yönelik çalısmalarını yürütmektedir. Yatırım destek ofisimizle yatırımcıları çekmek ve yatırım yapılan bölgeyi tanıtmak üzerine çalışılmaktadır. İstanbul bölgesinde bu iş için tek etken Kalkınma Ajansı değildir. Bunun yanı sıra Büyükşehir Belediyesi, İl Kültür Turizm Müdürlüğ̈̈, Başbakanlık Yatırım Destek Ofisi gibi kurumlar ile iş birliği yapılarak süreç yürütülmektedir".

Metropol şehirlerin dünya üzerinde olumlu yönde tanıtımının yapılması gerek yabancı yatırımcıların çekilmesi gerekse dış dünyada o şehre karşı olumlu bir algının oluşması yönünden önemli görülmektedir. Bu bakımdan festivaller, fuarlar, spor organizasyonları gibi çeşitli etkinlikler ile şehir canlı tutularak gündeme getirilmeye çalışılmaktadır. Buradan hareketle katılımcıya "İstanbul ilinin tanıtımı için yapmış olduğunuz faaliyetler nelerdir?" sorusu yöneltilmiş ve yapılan faaliyetlere yönelik aşağıdaki şekilde cevap alınmıştır:

"Yatırım destek ofisinin faaliyetleri tanıtıma katkı sağlamaktadır. Yatırımcılara yönelik tanıtım faaliyetleri ise düzenli olarak yapılmaktadır. Doğrudan tanıtıma yönelik 2 dönem boyunca Shopping Fest'e katkr sağlanmıştır. Bu festivali yabancılara tanıtabilmek için tanıtım boyutu desteklenmiştir. Bununla birlikte mali destek programı içerisinde tanıtım yapacak platformlar desteklenmiştir. Burada doğrudan olmasa da tanıtımın yapılacağı iş birlikleri desteklenmiştir".

Kalkınma Ajansları sahip oldukları bütçeler ile birçok sektöre doğrudan destek programları ile maddi destekler sağlamaktadır. Özellikle turizm sektörüne yönelik çok sayıda proje çağrısında bulunulduğu söylenebilir. Ancak diğer programlarda olduğu gibi turizm sektörüne yönelik olarak hazırlanmış destek programlarına da yeterli ilginin gösterilmediği ifade edilmiştir. Konuyla ilgili olarak katılımcının "Turizm için destek programlarınızdan ne ölçüde yararlanıldığını düşünüyorsunuz?" sorusuna vermiş olduğu cevabın tamamı şu şekildedir:

“Diğgr programlarımızda olduğu gibi turizmde hazırlanmış destek programlarımızın yeterli ilgiyi gördüğ̈̈̈nü düşünmüyoruz. Büyük bir bütçemiz olmasina rağmen bu bütçemizin tamammı kullandıramıyoruz. Burada önemli olan yüksek nitelikli projelerde gelinmesi olmaktadır. Aksi taktirde değerlendirmeden geçememektedir. Dolayısıyla fikri olanın iyi proje üretmesi, nitelikli ürünler ortaya koyması, bahsedilen önceliklere uygun projeler üretebiliyor olması gerekmektedir. Özellikle işletmeler tarafından daha çok faydalanılabilir. Bölgede bu kapasiteyle ilgili bir sıkıntı olduğunu tespit edebiliyoruz. ISTKA bölgesi son dönemde bu fon kapasitesini artırmıştır. Bu süreçle ilgili proje döngüsü eğitimleri devam etmekte ve ajansin tanınırlğ̆ının artmasının da bunda katkısı olmaktadır. 


\section{SONUÇ ve ÖNERILER}

Kentlerin marka kent haline getirilmeleri noktasında; kentin tarihi ve kültürel değerleri, fiziki şartları, coğrafi konumları, somut olmayan kültürel değerleri ve ekonomileri önemli birer belirleyici olmaktadır. Köklü bir tarihsel geçmişe sahip olan ve topraklarında eski dönemlere ait yaşanmışlıklar bulunan kentler bu özelliklerini kentin tanıtılması ve markalaşması için kullanmaktadırlar. Aynı şekilde düzgün fiziksel şartlara sahip kentler de bunu kullanabilmektedir. Nevşehir ili sınırında bulunan Peribacalarının doğal güzellikleri, burada önemli bir markalaşma faaliyeti olabilmektedir. Diğer önemli bir belirleyici ise coğrafi konum noktasında olabilmektedir. Örnek verildiğinde jeopolitik olarak kilit noktalarda bulunan kentlerin markalaşma faaliyetlerinde bu yönünü kullanmaları şehre artı değer katabilmektedir. Bazı kentlerle özdeşleşmiş geçmişten beri süren gelenek ve görenekler o şehri bir marka haline getirebilmektedir. $\mathrm{Bu}$ da somut olmayan kültürel değerlerin o yöreyle ilgili önemini vurgulamada önem teşkil etmektedir. Güçlü bir ekonomiye sahip olan kentlerin markalaşma faaliyetlerine ayırdıkları paylar da buna paralel olarak fazla olmaktadır. Bu sayede de yapılan faaliyet sayısı artmakta ve başarı oranı yükselmektedir. Tüm bu özelliklerin dışında gelişen dünyayla birlikte bölgelerin ve kentlerin kalkınmasına yönelik Türkiye'de ve dünyada bazı kuruluşlar ortaya çıkmaya başlamıştır. Kalkınma ajansları da bölgesel gelişimi desteklemek üzere Türkiye genelinde örgütlenmiş olan kuruluşlardandır.

Ülke genelinde yayılmış olan kalkınma ajanslarından İstanbul bölgesinin bağlı olduğu birim ise İSTKA olarak adlandırılan İstanbul Kalkınma Ajansıdır. Bu ajans İstanbul bölgesinin gelişmesine yönelik; strateji geliştirme, destekleme ve bu stratejileri hayata geçirme gibi faaliyetler ile ilgilenmektedir. Mali destek programları sayesinde koymuş olduğu hedefler doğrultusunda kişilere ve kuruluşlara proje çağrısı yaparak İstanbul'un gelişimi için yeni fikirlerin doğmasını sağlamaktadır. Bu araştırma genelinde kalkınma ajanslarının bulunduğu bölgeye, turizm potansiyelinin artırılmasına ve sürdürülebilirliğine ne gibi katkılar sağladığı, gerçekleştirdiği uygulamaların kentlerin markalaşma sürecine ne gibi katkıları olduğu, İSTKA'nın TR10 bölgesinin turizm potansiyelinin artırılmasında, sürdürülebilir ve marka bir bölge olmasında ne gibi etkilerinin olduğu, turistik bir ürün olan destinasyonların kalkınma ajansları için önemi ile kalkınma ajansının belirlediği ve ulaştı̆̆ 1 hedefler arasındaki uyum ortaya çıarılmaya çalışılmıştır.

Görüşme tekniğiyle toplanan verilerden elde edilen sonuçlarda en dikkat çeken konu "Turizm için destek programlarınızdan ne ölçüde yararlanıldığını düşünüyorsunuz?" sorusuna verilen yanıt olmuştur. Diğer programlarda olduğu gibi turizmde de hazırlanan destek programlarına yeterli ilginin gösterilmediği, önemli bir bütçe olmasına rağmen bu bütçenin tamamının kullandırılamadığı konusu önemli bir sorun olarak karşımıza çıkmaktadır. Bu konuda yüksek kalitede ve nitelikli projelerin üretiminin az olması bunun en büyük sebebi olarak görülmektedir. Günümüzde gerek ülkesel bazda gerek bölgesel bazda markalaşmanın önemli olduğu görülmektedir. Kalkınma ajansı gibi kurumlar ise bu ve bunun gibi gelişme faaliyetlerinin önemli destekleyicileri konumundadır. Araştırmada da bir kez daha değinildiği üzere kullanılmak üzere ayrılmış olan, ancak tamamının kullanılamadığı bu bütçeden konuyla ilgili nitelikli projeler hazırlayarak gerek özel sektör temsilcileri gerekse diğer toplum kuruluşları kalkınma faaliyetlerine destek verebilir.

Literatürde yapılmış benzer çalışmalara bakıldığındaysa; Özkul ve Demirer (2012) Kalkınma Ajanslarının bulundukları bölgedeki şehirlerin markalaşması üzerindeki rollerini belirlemeye yönelik olarak yaptıkları çalışmalarında ajansların bölgelerdeki turizm değerlerini belirleyerek şehrin markalaşması için hedefler koyarak hazırladıkları projelerle turizm talebini oluşturmaya çalıştıklarını belirtmişlerdir. Can ve Kazancı-Başaran (2014) Rize ilinin kent markası ve imajını 
belirlemeye yönelik yapmış olduğu araştırmada ilin tanınırlığında turizm potansiyelinin önemli katkıları olduğunu belirtmiş ve kent imajı arttıkça turizm çeşitliliği ile turizm gelirinin de artacağını ifade etmiştir. Polat ve Özdemir-Yılmaz (2014) kalkınma ajanslarının turizmin gelişmesindeki rolünü inceledikleri araştırmalarında kalkınma ajanslarının kültürel zenginliğin ortaya çıkarılmasında, turizmin gelişmesinde, sağlık ve termal alandaki mevcut durumun güçlendirilmesinde ve ikinci konut sorunlarının ortadan kalkmasında önemli hedeflerinin olduğunu ortaya koymuştur. Çalışkan ve Toy (2016) kalkınma ajanslarının planlama ve finansman açısından turizm sektörüne sağladığı katkılar üzerine yapmış olduğu araştırmada Türkiye'deki 26 kalkınma ajansının hepsinin turizm sektörü ile ilgilendiklerini belirtmişlerdir. Çalışmada ajans bütçelerinden özellikle turizmde altyapı ve tanıtım konularına ayrılan kaynağın boyutu ile ilgili somut fikirler elde edilmiştir.

Bu anlatımlar ışığında kalkınma ajansları bulundukları bölgeye strateji geliştirme, destekleme ve bunları hayata geçirme noktasında etkin olarak destek sağlamaktadır. Kurum olarak farklılaşmayı savundukları için turizm sektöründe alternatif turizm faaliyetlerine özel ilgi göstermekte ve turizm sektörüne önemli katkılar sağlamaktadırlar. Turizmde koruma-kullanma dengesine dikkat edilmesi sürdürülebilirliğin önemini ortaya koymaktadır. Ajans İstanbul'un markalaşmasına yönelik ilgili kuruluşlarla iş birliği yaparak önemli adımlar atmaktadır. İstanbul Tanıtım Ofisi'nin kurulmasıyla ilgili çalışmalar buna örnek verilebilir. İstanbul bölgesinin turizm potansiyelinin arttırılmasında, sürdürülebilir ve marka bir kent olmasında İSTKA'nın önemli katkıları bulunmaktadır. Bunda alternatif turizm türlerine yönelik olarak yaptığı çalışmalar ile iki dönem boyunca turizme yönelik olarak desteklenen projeler ve Shopping Fest gibi aktiviteleri destekleyerek şehrin tanıtımına yapılan katkılar örnek gösterilebilir. Ayrıca turistik bir destinasyon olan İstanbul'un komple bir kent olarak markalaşması gerekliliği üzerinde durulmuş ve İstanbul destinasyonunun İSTKA için bu yönüyle de önem teşkil ettiği savunulmuştur. Kalkınma ajansları belirlediği hedeflere genel itibariyle ulaşabilmektedir. Bunda en önemli olan etken desteklemiş olduğu projeleri sıkı bir ön değerlendirmeden geçirmesi, süreç içerisinde ve sonunda denetiminin sıkı yapılması gibi etmenler gösterilebilir. Bu kapsamda İstanbul Kalkınma Ajansının kısa süre içerisinde kurumsallaşmasını tamamlaması ve bu denli gelişme göstermesi de ajansın gelecekteki hedeflerine ulaşmada emin adımlarla ilerlediğini göstermektedir.

Diğer yandan Kalkınma Ajanslarının turizm paydaşları ile iş birliği içerisinde olması da büyük önem taşımaktadır. Ajansın belirli dönemlerde hazırlamış olduğu doğrudan destek bütçelerinde turizm sıklıkla yer almaktadır. Örneğin Doğu Karadeniz Kalkınma Ajansı 2020 yılı mali destek programı kapsamında Sürdürülebilir Turizm ve Destinasyon Yönetimi konusundaki projeleri desteklemek üzere 10.000.000 TL program bütçesi ayırmıştır. Yine araştırma alanı olan İstanbul Kalkınma Ajansı da 2015 yılında Sağlık Turizmi, 2016 yılındaysa Yenilikçi İstanbul temalarıyla turizm ve hizmet sektörüne yönelik çok sayıda projeyi desteklemiştir. Bu bakımdan turizm paydaşları olan seyahat işletmeleri, otel işletmeleri, yiyecek içecek işletmeleri, sivil toplum kuruluşları ve kamu kurumları birlikte hareket ederek, sektörün ihtiyaçlarını tespit etmek ve geliştirebilmek üzere projeler hazırlayabilmelidir. Özel sektör projeler hazırlarken kamu kurumlarının öncülük etmesini beklememeli, kendisi projeler hazırlayarak sivil toplum kuruluşları ve büyük şirketler tarafından desteklenen kurumsal sosyal sorumluluk projeleri ile de kendilerine destek sağlayabilmelidir.

Araştırma, İstanbul ve bölgesinin tercih edilen bir bölge olabilmesi için sahip olduğu avantajlardan hangilerinin, ne derecede kullanıldığını belirleyebilmek için İstanbul bölgesini kapsayan İstanbul Kalkınma Ajansında görevli uzmanlar ile yapılan görüşmeleri kapsamaktadır. Gelecek çalışmalarda diğer bölgeleri de kapsayan çalışmalar yapılarak konuyla ilgili kapsam daha da genişletilebilir. Ayrıca Kalkınma Ajanslarının kurulmuş oldukları yıldan bugüne kadar turizm sektörüne yönelik olarak vermiş oldukları destekler içerik analizi ile incelenebilir. 


\section{KAYNAKÇA}

Akpınar, R. (2010). Türkiye'de Kalkınma Ajanslarınca Hazırlanan Bölge Planlarına Dair Bir Kritik: İZKA'nın İzmir Bölge Planı (2010-2013) Örneği, Dokuz Eylül Üniversitesi Sosyal Bilimler Enstitüsü Dergisi,12 (4), 07-18.

Akpınar, R., ve Keskin, R. (2018). Zafer Kalkınma Ajansı'nın Manisa Ekonomisine Katkısı. Yüzüncü Yıl Üniversitesi Sosyal Bilimler Enstitüsü Dergisi, (40), 207-226.

Buhalis, D. (2000). Marketing the Competitive destination of the Future, Tourism Management, 21 (1), 97-116.

Büyüköztürk, Ş. (2014). Örnekleme Yöntemleri. Ankara: Pegem Akademi Yayıncılık.

Can, M. C. ve Kazancı-Başaran, Z. (2014). Kent Markası ve İmajının Belirlenmesi: Rize Örneği. Marmara Üniversitesi Öneri Dergisi, 11 (42), 27-42.

Cevher, E. (2012). Kentsel Markalaşma Süreci: Antalya Örneği. Sosyal ve Beşeri Bilimler Dergisi, 4(1), 105-115.

Çalışkan, U. ve Toy, S. (2016). Kalkınma Ajanslarının Planlama Ve Finansman Açısından Turizm Sektörüne Sağladığı Katkılar. Dokuz Eylül Üniversitesi Isşletme Fakültesi Dergisi, 17(2), 141-160.

Çelik, F. (2019). Bölgesel Kalkınma Ajanslarının Sosyal Kalkınmaya Katkısı: İzmir Kalkınma Ajansı (İzka) Örneği. Mehmet Akif Ersoy Üniversitesi Sosyal Bilimler Enstitüsü Dergisi, 9(19), 148170.

Çiftçi, G., Çakır, A. and Çakır, G. (2016). The Role of Trakya Development Agency on Thrace Region Tourism. Journal of Tourism Theory and Research, 2 (2), 159-172.

Diker. E. (2018). İmaj ve Türleri, İmaja Dair Her Şey içinde, Editör: Özüpek, M.N: Marka İmajı içinde (ss.45-69) Konya: Eğitim Yayınevi.

Ergun, C. (2012). Küreselleşme, Küresel Kent ve Kentsel Dönüşüm, Sosyal Demokrat Dergi, [Online] http://www.sosyaldemokratdergi.org/kuresellesme-kuresel-kent-ve-kentsel-donusum/ [Erişim Tarihi: 12.09.2019].

Eroğlu, H. (2007). Şehirlerin Markalaşması, Yerel Siyaset Dergisi, 23, 65-68.

Giritlioğlu İ. ve Avcıkurt, C. (2010). Şehirlerin Turistik Bir Ürün Olarak Pazarlanması, Örnek Şehirler ve Türkiye'deki Şehirler Üzerine Öneriler (Derlemeden Oluşmuş Bir Uygulama), Adıyaman Üniversitesi Sosyal Bilimler Enstitüsü Dergisi, 3 (4), 74-89.

Hanna, S. and Rowley, J. (2008). An Analysis of Terminology Use in Place Branding. Place Branding and Public Diplomacy, 4 (1), 61-75.

https://istanbul.ktb.gov.tr/TR-217234/yabanci-ziyaretcilerin-ortalama-kalis-suresi-28-tesisle.html [Erişim Tarihi: 15.09.2019].

https://istanbul.ktb.gov.tr/Eklenti/68945,aralik-2019-turizm-istatistikleri-istanbulpdf.pdf?0 [Erişim Tarihi: 15.02.2020].

http://www.tuik.gov.tr/PreTablo.do?alt_id=1072 [Erişim Tarihi: 10.01.2020].

https://www.ktb.gov.tr/TR-96269/turizm-cesitleri.html [Erişim Tarihi: 01.03.2020].

https://www.doka.org.tr/destek_2020-YILI-SURDURULEBILIR-TURIZM-VE-DESTINASYONYONETIMI-MALI-DESTEK-PROGRAMI-TR.html [Erişim Tarihi: 25.02.2020].

https://www.istka.org.tr/tr/kurumsal/organizasyon-yapisi/ [Erişim Tarihi: 01.09.2019]. 
Işık, N. Baysal, D. ve Ceylan, O. (2010). Bölgesel Kalkınma Farklılıklarının Giderilmesinde Bir Politika Aracı Olarak Kalkınma Ajansları. Niğde Üniversitesi İ.̇.B.F Dergisi. 3 (2), 1-18.

İçellioğlu-Şarkaya C. (2014). Kent Turizmi ve Marka Kentler: Turizm Potansiyeli Açısından İstanbul'un SWOT Analizi. İstanbul Üniversitesi Sosyal Bilimler Dergisi, 1, 37-55.

İlgüner, M. ve Asplund C. (2011). Marka Şehir, İstanbul: Marketing Yayınları.

Kanıbir, H., Nart, S. ve Saydan, R. (2010). Şehir Pazarlamasında Marka Kişiliğinin Etkisi: Algılanan Marka Kişiliği-Turistlerin Tavsiye Etme Davranışı İlişkisi. Pazarlama ve Pazarlama Araştırmaları Dergisi, 6, 53-84.

Kotler, P. (2004). Opinion Pieces Where is Place Branding Heading?, Place Branding, 1 (1), 12-35.

Kültür ve Turizm Bakanllğ 1 (2007). Türkiye Turizm Stratejisi. https://www.ktb.gov.tr/Eklenti/906,ttstratejisi2023pdf.pdf?0 [Erişim Tarihi: 15.09.2019].

Lincoln, Y. S. and Guba, E. G. (2010). Naturalistic Inquiry. 1985. Newbury Park. Calif.: Sage Publications.

Özdemir, Ş. ve Karaca Y. (2009). Kent Markası ve Marka İmajının Ölçümü: Afyonkarahisar Kenti İmajı Üzerine Bir Araştırma, Afyon Kocatepe Üniversitesi, İ.I.B.F. Dergisi, 11 (2), 113-134.

Özer, M. A. (2012). Türkiye' de Bölgesel Kalkınma Ajanslarının Sosyal Ekonomik İşlevleri. Kamu$\dot{I}_{\text {Ş, }} 12(2), 37-74$.

Özkul E. ve Demirer, D. (2012). Şehirlerin Markalaşmasında Kalkınma Ajanslarının Rolü, Bölge Planları Üzerine Bir Doküman İncelemesi. İşletme Araştırmaları Dergisi, 4 (4). 157-181.

Patton, M. Q. (1990). Qualitative Evaluation and Research Methods. SAGE Publications, Inc.

Polat, E., ve Özdemir Yılmaz, G. (2014). Kalkınma Ajanslarının Turizmin Gelişmesindeki Önemi: Güney Marmara Kalkınma Ajansı Örneği. Journal of Entrepreneurship \& Development/Girişimcilik ve Kalkınma Dergisi, 9(1):137-160.

Porter, M. E. (1995). The Competitive Advantage of Inner City, Harvard Business Press, 73 (3), 5571.

Şimşek, A. (2013). Kalkınma Ajanslarının Performans Ölçümü. Devlet Planlama Teşkilatı Yayımlanmış Uzmanlık Tezi. Ankara.

Tavşancıl, E., ve Aslan, A. E. (2001). Sözel, Yazılı ve Diğer Materyaller İçin İçerik Analizi ve Uygulama Örnekleri. İstanbul: Epsilon Yayıncilık.

Tek, M. (2009). Kamu Yatırımlarında Turizmin Yeri, Türkiye Turizm Stratejisi 2023'de Marka Kentler Projesi: Eleştirel Bir Değerlendirme, Anatolia: Turizm Araştırmaları Dergisi, 20 (2), 169-184,

Tekin, M. ve Cici E. N. (2011). Şehirlerin Markalaşma Sürecinin Yansımaları: Konya İli Üniversitelerindeki Öğrencilerin Algılarındaki Konya Markası. XI. Üretim Araştırmaları Sempozyumu, 23-24 Haziran 2011, Konya.

Toksarı, M., İsen, İ. ve Dağcı, A. (2014). Bir Şehrin Markalaşması ve Pazarlanması Süreci: Konya İlinde Bir Uygulama, Niğde Üniversitesi İ̈BF Dergisi, 7 (1), 328-343.

Tosun, C. ve Bilim, Y. (2004). Şehirlerin Turistik Açıdan Pazarlanması, Anatolia Turizm Araştırmaları Dergisi, 15 (2), 125-138.

Türnüklü, A. (2000). Eğitimbilim Araştırmalarında Etkin Olarak Kullanılabilecek Nitel Bir Araştırma Tekniği: Görüşme. Eğitim Yönetimi, 6 (4), 543-559. 
Uçar, A., ve Başaran, İ. (2019). Kalkınma Ajanslarının Girişimcilik ve İstihdamı Artırma Hedeflerinin Değerlendirilmesi: Zafer Kalkınma Ajansı Örneği. Paradoks: The Journal of Economics, Sociology \& Politics, 15(2): 121-136.

Yıldırım, A., ve Şimşek, H. (2008). Sosyal Bilimlerde Nitel Araştırma Yöntemleri (6. Baskı). Ankara: Seçkin Yayıncılık.

Yılmaz, K. ve Özdem, G. (2004). Norm Kadro Çalışmalarının Üniversitelerde Uygulanabilirliği: Nitel Bir Araştırma. Ankara Üniversitesi Eğitim Bilimleri Fakültesi Dergisi, 37 (2), 115-136.

Zeren, H. E. (2012). Kent Markalaşması Sürecinde İç Girişimcilik Faktörü. Kahramanmaraş Sütçü İmam Üniversitesi İktisadi ve İdari Bilimler Fakültesi Dergisi, 2 (1) 95-104. 